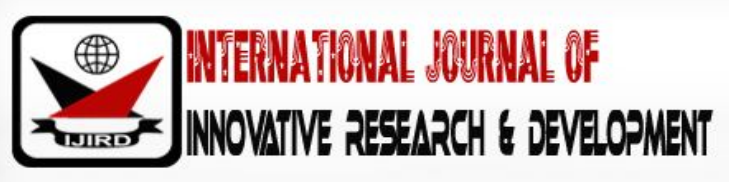

ISSN 2278 - 0211 (Online)

\section{The Social Networking among Secondary School Students In Anambra State: Educational Implications For Counsellors}

\author{
Dr. Egenti, Uju. P.
Department Of Educational Foundations,
Faculty of Education, Chukwuemeka Odumegwu Ojukwu University, Igbariam Campus, Anambra State, Nigeria
(Formerly Anambra State University, Uli)
Prof. R.C. Ebenebe
Department of Educational Foundations,
Faculty Of Education, Nnamdi Azikiwe University, Awka, Nigeria
}

\begin{abstract}
:
The study examined social networking and the academic performance of secondary school students with focus on counselling implications. It was carried out in Anambra State. The descriptive survey research was adopted using questionnaires as instrument for data collection. The questionnaire was admitered personally by the researcher to the sample of 2250 SS II secondary school students selected from the six education zones in Anambra state using simple random sampling technique.Mean ratings were used in data analysis. The findings revealed that social networking has both positive and negative implications on the users. Positively it allows students to share information, ideas as well as gain knowledge among others. Whereas the negative use of social networking is distracting students from their studies. It is recommended that students should be counselled on the effective and appropriate use of social networking. Parents are advised to ensure that their wards and children spend quality time in reading their books than chatting on social networking sites. Finally government at all levels and ministries of education can make policies restricting the use of handset while schools are in session.
\end{abstract}

\section{Introduction}

The revolutionary effects of information and communication technology (ICT) are felt in almost all facets of human life. More than ever before, the knowledge and capability for ICT have become a common denominator in all human interactions. According to Daniels (2002), ICT has, within, a very short time, become one of the basic building blocks of modern society. ICT has turned the whole world into a global village, making it possible to foster interaction with people in remote geographical locations at an unimaginable speed (Ogbaga 2010).

A more practical and relevant definition of ICT was given by the World Bank. ICT consists of the hardware, software, networks, and media for the collection, storage, processing, transmission and presentation of information (Voice, data text, images), as well as related services (World Bank, 2007). This probably moved Ogbaga (2010:8) to define ICT as "the range of technologies that are applied in the process of collecting, storing, editing, retrieving and transfer of information in various forms". He further gives the components of ICT to include: social media and social networking, computers, mobile telephones, MP3/ MP4/ WMA storage devices, file transfer protocols, listservs, world wide web and other electronic means of information exchange among people. According to Chen and Kee (2005), ICT is the backbone of the knowledge economy and in recent years, have been recognized as an effective tool for promoting economic growth and sustainable development. Of all the components of ICT, social networking is enjoying a considerable popularity today and thus, forms the major focus of this study. The world is a global village today as a result of the use of interest, hence making social networking possible. The invention of social networking has dramatically changed the internet world. As observed by Boyd and William (2007) teenagers to elderly now exchange ideas via social sites like Facebook, Twitter, 2go, MySpace, Badoo, Palmchat. Whatsapp and many others: Walter and Rivera (2004) notes that social networking websites allows users to be part of a virtual community and the most popular sites are facebook, Whatsapp and MySpace. These networks provide users with simple tools to create a custom profile with text and pictures. A typical profile includes basic information about the user, at least one photo, and possibly a blog or other 
comments published by the user. Advanced profiles may include video, photo albums, online applications (in facebook), or custom layouts (in MySpace). After creating a profile, users can add friends, send massages to other users, and leave comments directly on friend's profiles. These features provide the building blocks for creating online friendship and communities.

As noted earlier, the invention of the internet and social networking sites are of immense benefit to the modern man. They have enhanced the means of communication and information. Lusk (2010) supporting the above view notes that the use of these networks enable students to have access to information that can help them academically. But he however notes that social network can only be useful to the student when properly used. That means that if these networks are not properly appropriated, they can as well have negative effects on the academic performance of the student.

Education has to do with acquiring information and certain knowledge that brings about personal transformation. The aim is to help the individual learn about the acceptable societal norms and values and thus be able to adapt to his/ her society. Sandra (2013) opines that education is a very powerful instrument. It is however important to know that education, knowledge, information are related, can either be, according to Sandra (2013) destructive or constructive weapons. Through the use of social networks and the internet, students have access to all types of information and knowledge. Some of these information are however destructive. It has been observed that many students instead of using the internet and social networks to access useful (academic) information are drawn or goaded into cyber crimes, sexchatting and/ or sexting. Thus, such students become vulenerable to becoming preoccupied with pornography.

Though, social network sites are meant for connecting people-a medium whereby people can socialize and communicate with each other ; share video and pictures, there is no doubt that students are getting addicted to these social sites and they not only affect their academics but also their physical, social, mental, spiritual lives and growth. During classes, many students prefer chatting online with their pals while some go to the extent of watching pornography than listening to their teachers. Hence Parrack (2012) notes that social networks could cause distraction, thus harmful to their academic performances and productivity.

Social network is an internet application that allows users to interact, share ideas, express their feelings, disclose personal information and data, which include pictures and videos at a very increasing high rate and speed. In support of the above idea,Walter and Rivera (2004) noted that social network has to do with the connection or relationship that exists between the networks of people.

Boyd and Ellison (2007) however give different contents that allow a social network user to connect and interact with other users, construct a people, articulate list of other users. In these profiles, the data of the user will be revealed to other users to access-such data include name, relationship status, occupation, photos, videos, religion, ethnicity and personal interest.

Ellison and Ahn, both accept the views of Sunden (2003) that the social network is one of the outstanding ways of brining oneself into being. The researcher would want to agree with these views. For example, the use of Facebook allows users to view or access other people's profile-such as their age, location, uploaded pictures and videos etc.Having examined what social network is all about; the next question that comes to one's mind is, where did all these begin? Who paved the way for the likes of twitter and Facebook? This will make the researcher to briefly trace the history of social networks.

Ellison (2006) notes that in the year 1997, the first social network called Six Degrees was launched. It allowed users to create profiles and become friends with other users. Whilst it is no longer functional, it was quite popular with around one million users at its peak. After been attracted to many users, it failed to become a sustainable business and for this reason, in the year 2000, the service closed down.

From 1997 to 2001, after the closed down of Six Degrees other social networking sites were launched to the public. To mention but few, they include Asian Avenue, Blackplanet, Faceparty and Migante which allowed users to create personal, professional profiles and interact with each other using forums and messaging facilities. Friendster was launched in 2012. It was designed to help friends-of-friends meet, based on the assumption that friends-to-friends would make better romantic partners than would strangers. Friendster grew to about 300,000 users through mouth advertisement before taking it to the press for proper coverage.

In the year 2003, another networking site was launched as a clone of Friendster called MySpace. In 2004, another social networking websites was started for students at Harvard College. It was referred to at the time a college version of "Friendster". In the year 2005, Facebook lunched a version for high school students, professionals inside corporate networks, and eventually everyone. In the same year Youtube began storing and retrieving videos. Unlike other social network sites, Facebook users are unable to make their full profiles public to all users. Another feature that differentiates Facebook is the ability for outside developers to build "application: which allow users to personalize their profiles and perform other tasks, such as compare movie preferences and chart travel histories. In 2006, twitter was launched as a social networking and microblogging site, enabling members to send and receive 140-charcters messages tweets. Google had indexed more than 25 billion Web pages, 400 million queries per day; 1.3 billion images and more than a billion use net messages (Francesca 2010). In 2009, Facebook ranked as the most used social network world wide with more than 200 million users. The internet had at least 27 billion web pages and could have had as many as 58 million web pages. They changed so many times a day it was nearly impossible to count. 
In 2010 Facebook's rapid growth moved it above 400 million users, while MySpace users declined to 57 million users, down from a peak of about 75 million. To compete with the likes of Facebook and Twitter, Google launched Buzz, a social networking site integrated with company's Gmail. Rotimi (2010) reports that in the first week, millions of Gmail user created 9 million posts.Barnes (2006) notes that from 2011-12 social media were accessible from virtually anywhere and had become an integral part of our daily lives with more than 50 million people on Facebook, 65 million tweets sent through twitter each day and 2 million video views every day on Youtube.

It is evident that the use of social network has surpassed the likes of Newspapers as a primary way to get news. The internet was the third most popular news platform, with many users looking to social media and personalized feeds for history of social networks, the researcher wishes to appraise social networking among secondary school students in Anambra State with some counselling implications.

\section{Purpose of the Study}

The main purpose of the study was to ascertain social networking among secondary school students inAnambra State with counselling implications for ensuring positive use of social networking among students.

Specifically, the study ascertained:

1. Extent students in secondary schools in Anambra State engage in social networking.

2. Experiences of the students as they engage in social networking.

3. Extent social networking influence the academic performance of students in the secondary schools.

4. Possible ways school counsellors canensure the positive use of social networking among students.

\section{Research Questions:}

The following research questions guided the study:

1. To what extent do students in secondary schools in Anambra State engage in socialnetworking?

2. What exactly are the experiences of the students as they engage in social networking?

3. To what extent does the social networking influence the academic performance of students in the secondary schools?

4. What are the possible ways school counsellors canensure the positive use of social networking among students?

\section{Research Method}

This research is a descriptive survey. Hence, a descriptive survey design was used. In this method, a group of people is studied by collecting and analyzing data from only few people which are taken to be representatives of the entire group. Survey method according to Atoyebi (2013) makes use of instruments like oral interview and questionnaire.

This study was carried out in Anambra State. The state has six education zones namely: Aguata, Awka, Nnewi, Ogidi, Onitsha and Otuocha. The population of the study comprised all the 16571 SS II students in six education zones of Anambra State. Data collected from the Anambra State Post Primary Schools Services Commission, Awka, (June, 2015) revealed that the state has a total of 252 secondary schools with 7715 male and 8856 female SS II students respectively. The focus of this study is on SSII students. This is because they have been in the system long enough to experience a good impact of the school system. While the SSI students might be new in the senior school system, the SS III students might be too busy preparing for their WAEC and NECO examinations. It therefore seems more appropriate to focus on SS II students in the study. The sample of this study comprised 2250 SS II secondary school students selected from the six education zones in Anambra state using simple random sampling technique. Before the students were selected, 5 schools were first sampled from each education zone using proportionate stratified random sampling with replacement which gave a total of 30 secondary schools. Then, 75 SS II students were selected from each of the 30 schools giving a total of 2250 SSII students constituting $14 \%$ of the total population.

Self-administered questionnaires (as an instrument for data collection) which were in form of lose and open ended questions were designed, validated and distributed to the students at the various schools. The questionnaire has two (2) major parts. Part "A" contains the respondents' personal data; while "B" contains question items on the use of social network among students, its effects and possible remedy.The retrieved data were put in tabular forms in tables; mean ratings were used for the data analysis.

\section{Data Presentation and Analysis}

The data were analyzed and presentedfor each of the questionnaire as test for the research questions. These are presented on the tables below: 
Research Question 1: To what extent do students in secondary schools in Anambra State engage in socialnetworking?

\begin{tabular}{|r|c|c|c|}
\hline & As a Student, to What Extent Do You: & Mean (x) & Dec. \\
\hline 1. & $\begin{array}{c}\text { Agreewith the fact that many students are getting preoccupied with } \\
\text { the social network? }\end{array}$ & 3.41 & VGE \\
\hline 2. & $\begin{array}{c}\text { Agree that most students spend quality time chatting on social } \\
\text { networks because they have less academic workload. }\end{array}$ & 2.11 & LE \\
\hline 3. & $\begin{array}{c}\text { Agree that most students make use of the social networking sites to } \\
\text { make and chat with online friends }\end{array}$ & 3.82 & VGE \\
\hline 4. & $\begin{array}{c}\text { Agree that many students prefer chatting on social network to reading } \\
\text { their books. }\end{array}$ & 3.54 & VGE \\
\hline
\end{tabular}

Table 1: Extent of Engagement in Social Networks among Students

Table 1. Showed that most of the items were rated to a very great extent. Only item 2 was rated low extent. It is obvious from the above data that the research question was answered in the affirmative. This means that many students are getting preoccupied with social networks than with their books and that through this means, they are able to make and chat with online pals.

Research Question 2: What exactly are the experiences of the students as they engage in social networking?

\begin{tabular}{|r|c|c|c|}
\hline & My Experience as a Student indicated that: & Mean (x) & Dec. \\
\hline 1. & Chatting on social networks reduces academic tensions and stress. & 3.41 & VGE \\
\hline 2. & Chatting on social networks is fun and exciting & 3.11 & VGE \\
\hline 3. & $\begin{array}{c}\text { Most students in the course of making use of social networks get } \\
\text { involved into sex chatting and sexting. }\end{array}$ & 3.82 & VGE \\
\hline 4. & $\begin{array}{c}\text { Many students are drawn into watching pornography and accessing } \\
\text { unhealthy materials. }\end{array}$ & 3.54 & VGE \\
\hline
\end{tabular}

Table 2: Experiences of Students with Social Networking

It is obvious from the above table 2 that in all the 4 items listed above were all rated to very great extent. Thus, based on the above data, it is pertinent that the research question was answered in the affirmative. This implies they chat on social network in order to ease academic pressure and have fun, however, they are also drawn to sex chatting and accessing unhealthy materials.

Research Question 3: To what extent does the social networking influence the academic performance of students in the secondary schools?

\begin{tabular}{|r|c|c|c|}
\hline & As a Student, I Maintain that: & Mean (x) & Dec. \\
\hline 1. & Social Network has effect on students academic performance. & 3.41 & VGE \\
\hline 2. & The use of social network is not okay for students. & 2.11 & LE \\
\hline 3. & $\begin{array}{c}\text { The use of social network among students gives room for } \\
\text { procrastination and academic laziness. }\end{array}$ & 1.82 & GE \\
\hline 4. & The use of social networks among students causes academic failure. & 3.54 & GE \\
\hline
\end{tabular}

Table 3: Influence of Social Networking on Students' Academic Performance

Table 3 above demonstrates that most of the respondents did agree with the items. The mean ratings for most of the items indicated that social networks has effects on the academic performances of students and thus, not okay for students. Only item two in the table was rated low extent; while others were rated to a great extent. This therefore implies that social network has effects on the students. Based on the above incidence, the researcher can thus infer that the research question for all the four (4) items was answered in the positive. 
Research Question 4: What are the possible ways school counsellors canensure the positive use of social networking among students?

\begin{tabular}{|r|c|c|c|}
\hline & As a Student, I Maintain that: & Mean (x) & Dec. \\
\hline 1. & Students should stop making use of the social networks. & 3.41 & VGE \\
\hline 2. & The government should prohibit the use of phone in schools. & 3.11 & VGE \\
\hline 3. & Students should stop making use of the social networks. & 3.82 & VGE \\
\hline 4. & $\begin{array}{c}\text { Parents should stop buying for their young ones phones that have } \\
\text { such application for downloading social networking sites. }\end{array}$ & 3.54 & VGE \\
\hline
\end{tabular}

Table 4: Implications for School Counsellors for Positive Social Networking

The data in the table 4 indicates that all the items were rated to very great extent.. From the above data, it can be inferred that the research question was answered in the positive. This means that the respondents believe that if the above measures are employed, then the problems and challenges posed by social networks would be minimized.

\section{Discussion of Findings}

The first research question sought to identify and find the effects of social network on the academic performances of senior secondary school students in Anambra State.Table 1 shows questionnaire items and data for answering research question one. According to the data analysis, most of the students engage in social networking. Since most of the responses are to a great extent, it can be inferred that the research question was answered in the positive. Due to the above incidence, the researcher can say that many respondents did agree that many students are getting preoccupied with social networks more than getting preoccupied with their studies. These days, students prefer chatting to their books.

The second research question sought to discover the experience of students as they make use of social networking sites. The results in the table show that the students experience a lot with social networks.Itis thus obvious that the positive response is higher than the negative responses-meaning the research question was answered in the positive. Social network users do face a lot challenges. Many students initially may not open these sites for accessing unhealthy materials, but the tendency is that often, as they visit and make use of these sites, they may be goaded into watching pornography, sexting and/ or sex chatting. Many of them many want to just chat with online and real friends and catch fun for just a while but end up spending many hours online.

The third research question sought to identify the influence of social networking on students' academic performance. The analysis of data for the research question showed that social networking has great influence on students' academic performance. For instance, one of the findings indicated that the use of social networks among students causes academic failure. This therefore has serious implications for school counsellors. This was explored by the fourth research question and the detailed discussion on this is presented under implications of the study.

\section{Conclusion}

In conclusion, it has been observed that everyone these days seem to be attracted to the social network; but it can be said that social network has its positive and negative effects in the life of its users. Social network has both positive and negative effects on students. It allows them to interact, share information, ideas, personal messages etc. it can also be used to gain knowledge and communicate with a long time friend. Whereas, the negative use of the social network is that it distracts the students from studying their books.

In summary, with this negative effects mentioned, some measures can be applied to encourage and maintain a rightful way of making use of the social network among students. Thiscan be done through good counseling on what ought to be done on the social networking sites and what not to be done. The help of parents will also be needed here, in making sure that their young ones spend enough time reading their books, doing their assignments than chatting on social networking sites. Adeyemi (203) agrees with the above view when he suggested that parents should place some restrictions on the lives of their children especially the time they spend on their phones, computers and every other gadget that allow them to make use of the social network.The government at all levels and school authorities can also help in making polices that restrict or prohibit the use of phones in school especially during school hours.

\section{Recommendations}

Based on the findings made in this study, the researcher hereby recommends the following:

1. That in order to shun or minimize the distraction caused by the use of social network, schools should ban the use of phones and other electronic gadget by their students. 
2. Various schools should sensitize, re-orientate and teach their students how they can use the social network to gain useful information and knowledge without being addicted to it.

3. The government should also initiate policies andor pass bills to prohibit or shut down networking sites that give room for pornography and fraud.

4. The parents should place some restriction on the lives of their young ones who make use of social network. They should thus monitor how their young ones make use of social networking sites.

5. Both governments owned and private schools should also stop the use of phones by students in schools.

\section{Educational Implications}

The findings of the study have implications for school counsellors and they are presented thus:

1. Students should be counselled to spend less time using the social networking sites and devote more time in their studies and self development.

2. Counsellors and parents too should always monitor how much time their young ones spend reading their books and making use of the social network. There should be balance in the way students make use of these networking sites.

3. School counsellors and teachers should always monitor students using their phones while classes are going on and penalize them.

4. School counsellorsshould encourage teachers to give their students more take-home assignments and monitor their academic progress and performances.

\section{References}

i. Adeyemi, D. (2013). An Examination of the Effect of Social Networks Among the youths of the Assembly of Gospellers' Chruch in Isolo Lagos State. (A Project being submitted to the Department of Religious and Biblical Studies of West Africa Theological Seminary, Ipaja Lagos).

ii. $\quad$ Bandura, A. (1997). Self-Efficacy: The Exercise of Control. NY, USA: W.H. Freeman Pub. House.

iii. Barnes, S. (2006). A Privacy Paradox: Social Networking in the United States. Routledeg: Cambridge MTT Press.

iv. Boyd, Danah and Ellison N. (2007). Why Youth (Heart) Social Network Sites: The Role of Networked Publics in Teenage Social life, A Decade in Internet Time: Symposium on the Dynamics of the Internet and Society. JCMC 13 (September):127.

v. Boyd, D. (2006). Friends. Friendsters and My Space Top8: Writing Community into being on Social Network Sites, Proceeding of ACM Press.

vi. $\quad$ Bruner, J.S. (1057). On Knowing: Essays for the Left Hand. Cambridge, Mass: Harvard University Press.

vii. Chen, D.H. and Kee H.L. (2005). A model on Knowledge and Endogenous Growth. World Bank policy research working paper 3539: World Bank.

viii. Daniels, J.S. (2002). Forward in Information and Communication Technology. In Education- A Curriculum for school andprogramme for teacher development. Paris: UNESCO.

ix. Ebony, W. (2010). A Social Society: The Positive Effects of Communicating Through Social Networking Sites. Online Conference on Networks and Communities.

x. Eldon, E. (2008). Growth Puts Facebook in Better position to Make Money. San Francisco, USA: Chicago, USA: ICA Press.

xi. Ellison, N. (2006). Spatially Bounded online Social Networks and Social Capital: The Role of Facebook. Chicago, USA: ICA Press.

xii. Jacobsen, W.C, \& Forste, R. (2011). The Weird Generation: Academic and Social Outcomes of Electronic Media Use Among University Students. New York, USA: MT Press.

xiii. Francesca, M. (2010). When Social Links re Network Links: The Dawn of Peer-to Peer Social Networks and its Implications for Privacy. Los Alamitos: IEEE Press.

xiv. June A. (2012). Teenagers' Experiences with Social Networks Sites: Relationships to Bridging and Bonding Social Capital, The Information Society (Journal Article).

xv. Kate, D. (2012). How Twenty Something Built one of Nigeria's Biggest Mobile Social Networks. Lagos: Meritz Publishing Press.

xvi. Knonpka, G. (1973). Requirements for Healthy Development of Adolescent Youth, "Adolescence. New York, NY: ACM Press.

xvii. Lenhart, A (2007). Cyberbullying. Washington, Dc: Pew Research Center; www.pewinternt.org accessed on the 11th of October 2012.

xviii. $\quad$ Lusk, B. (2010). Digital Natives and Social Media Behaviors: An Overview Palermo: Social Books Press.

xix. Macmillan Dictionary for Students, 1981. London: Macmillan Press Ltd.

xx. Melvin Et, al, (1993). Sociology, Human Society. Illinois' Foreman and Company Press.

xxi. National Campign to Prevent Teen and Uplanned Pregnancy. Sex and Tech: Results of a Survey of Teens and Young Adults. Washington Dc; National Campaign to prevent and unplanned pregnancy, 2008. 
xxii. Ogbaga, F.O. (2010). Information and Communication Technologies: A Basic Tool for Teacher Training and Manpower Development in Nigeria. Paper presented at the first national conference of the School of Arts and Social Sciences, Ebonyi State C.O.E.; Ikwo, 12 -16 April, at College Auditorium.

xxiii. Owolabi, F. (2009). Why Nigerians Have Poor Reading Culre:www.nigreianbest@forum.com accessed on the 4th of October 2014 Pearson, Erika. 2009. All the World Wide Web's a Stage: The Performance of Identify in Online Social Networks. Moody press.

xxiv. Pete, Cashmore. 2006. MySpace America's number one. Scotland: Mashable Publishing Company.

xxv. $\quad$ Qingya W. \& Wei Y.L. (2011). The Effects of Social Media on College Students. MBA Student Scholarship Paper.

xxvi. Rotimi T. (2010). The Handbook of Research on Discourse Behavior and Digital Communication: Language Structures and Social Interaction. Pennsylvania: IGI Global Press.

xxvii. Rubino, D, (2012). Microsoft Updates Skype for Windows Phone for Some Bug Fixes, Wpcentral.com. Mobile nations.

xxviii. Sano, D. (2009). Twitter Creator Jack Dorsey Illuminates the Site Founding Document. Los Angeles Times, 13 June, 8.

xxix. Schill, R. (2011). Social Networking Teens More Likely to Drink, Use Drugs, Study Finds.

xxx. $\quad$ Steel, E. (2011). MySpace Owners Timberlake, Specific Media Shrink Redesign Party. Cambridge: The Wall Street Press.

xxxi. Terry Freeman 2007. Social Networking form a Teen's Perspective. UK Magazine, 14 November.

xxxii. World Bank (2007). Education for All. Retrieved April 12, 2010, from http" web.worldbank.org/ WEBSITE/ EXTERNAL/ TOPICS/ EXTE 